Encounters on Education

Volume 3, Fall 2002, pp. 43 - 59

\title{
History, memory and learning to teach
}

\author{
Peter Seixas, Dan Fromowitz and Petra Hill \\ University of British Columbia; Saskatoon Public School Division; Vancouver \& \\ Richmond School Districts
}

\section{ABSTRACT}

How do individual and social memories get re-worked in the crucible of a teacher education program, as student-teachers prepare to teach history to the next generation in a democratic, multicultural, and multinational state? This study posits four key competencies that studentteachers need in order to transcend history as the simple transmission of social memory. It takes the form of intertwined autobiographical narratives of the three authors: two were studentteachers and the third, their instructor. It recounts their experience with memory and history prior to the teacher education program and then follows them through the program and into the schools. While it demonstrates their work with critical historical competencies, it also acknowledges a necessary persistence of issues of memory.

Keywords: social memory; collective memory; history education; student-teachers; teacher education; historical empathy; social studies; holocaust education

\section{RÉSUMÉ}

De quelle façon les mémoires individuelles et sociales sont elles retravaillées dans le creuset d'un programme de préparation des enseignants, tandis que les futurs enseignants se préparent à enseigner l'histoire à la prochaine génération dans un état démocratique, multiculturel et multinational? Cette étude-ci présuppose quatre compétences-clés dont les étudiants/enseignants ont besoin pour dépasser l'histoire vue comme une simple transmission de la mémoire sociale. Létude prend la forme de récits autobiographiques entrelacés par les trois auteurs, dont deux étaient étudiants/enseignants et le troisième, leur instructeur. Elle raconte leur expérience dans le domaine de la mémoire et de l'histoire avant le programme de préparation des enseignants et les suit durant le programme et jusque dans les écoles. Tout en démontrant leur travail en lien avec les compétences historiques critiques, l'étude reconnaît également une persistence nécessaire de questions de mémoire.

Mots clefs: mémoire sociale; mémoire collective; éducation en histoire; étudiants/enseignants; éducation des enseignants; empathie historique; études sociales; éducation sur l'holocauste 
RESUMEN

¿Cómo son reelaboradas las memorias individuales y colectivas en el crisol de la enseñanza cuando quienes van a ser profesores se preparan para enseñar historia a la nueva generación en un estado democrático, multicultural y multinacional? Este estudio propone cuatro competencias claves que los estudiantes de magisterio y professorado necesitan a fin de trascender una historia entendida como la simple transmisión de la memoria social. Adopta la forma de narrativas autobiográficas entrelazadas de los tres autores; de ellos, dos estudiaban para ser docentes y el tercero era su profesor. El artículo relata sus experiencias con la memoria y la historia antes de que tomasen parte en el programa de formación del profesorado, y las continúa durante la realización del programa y la práctica docente en las escuelas. Al mismo tiempo que demuestra el trabajo de los autores con las competencias históricas críticas, el articulo reconoce una persistencia necesaria de aspectos vinculados a la memoria.

Descriptores: Memoria social; memoria colectiva; enseñanza de la historia; estudiantes para profesores; formación del profesorado; empatía histórica; estudios sociales; enseñanza del holocausto.

\section{Introduction}

$\mathrm{M}$ UCH INK HAS BEEN SPILLED IN RECENT YEARS on the subject of history and memory. An easy dichotomy can be drawn: memory is the construction of the past which is immediately available, deeply held, profoundly meaningful, and therefore impervious to critique. History is the product of evidence-based investigation, rational dialogue, and dispassionate scholarship. Memory is the product of direct experience; history is the product of questioning, inquiry and critique (Kammen, 1995; Kansteiner, 2002; Klein, 2000; Nora, 1996; Samuel, 1994; Spiegel, 2002; Wertsch, 2002; Yerushalmi, 1989).

This simple bifurcation fails on many counts. It steers us away from the structures of social memory, as well as the deeply felt passions that stir people to engage in history. But this is not to suggest that the distinction can be eliminated. Rather, it is to propose that we scrutinize especially carefully the intersections between history and memory, passion, reason and meaning, dialogue and identity. These are the places where we will find the generative leaven that gives rise to our most thoughtful uses of the past.

What follows is a study of a history education program designed to initiate new teachers into a discipline-oriented understanding of the teaching of the subject. Memory was central, though it was rarely confronted explicitly in the teacher education program, either in the sense of the participants' individual memories of their life-experiences prior to the program, and in the social memories handed down to them through their families, schools, and other institutions. How do these memories get re-worked in the crucible of the teacher education program, as student-teachers prepare to work with the next generation, around the issues of history and memory, in the context of a democratic, multicultural, and multinational state?

We suggest that memory is crucial in what student-teachers (as well as their future students) bring to their encounters with the past in the present. And yet, we propose, it is equally crucial that they develop knowledge, approaches, and dispositions that transcend the simple transmission or evocation of memory. These can be conceptualized as four competencies which teachers must have, in order to be able to develop them in their own students. 
I They need to be able to formulate questions that can stimulate generative inquiry. These large questions often involve an ethical dimension and so

2 they need to understand the complexities of using the past to inform moral judgments in the present. Part of the difficulty in making sound judgments comes from operating across national, cultural, and temporal distance, and so

3 they need to appreciate the substantial challenges of historical empathy-rational understanding of other peoples across chasms of difference. And finally,

4 they must be able to interrogate texts critically as evidence in those inquiries, not simply to accept them as sources of information.

Only with these competencies can they begin to plan history lessons that will move their own students towards active and critical engagement with the past (Banks \& Parker, I990; Seixas, 1996; Seixas, 1998).

The research takes the form of intertwined narratives of three characters-the authors. Two were student-teachers in U.B.C.'s post-baccalaureate Teacher Education Program in 2000-200I. The third was the instructor in the social studies methods class, as well as the supervisor during 15 weeks of teaching practica. The narratives begin with our experiences of thinking about history and memory prior to the inception of the 2000-200I academic year. They trace our paths through the methods course in the Fall, and then - for the two student-teachers - into the practicum in the Spring.

Serendipity played a significant role in bringing us together as subjects and authors. Prior to entering the program, both Dan and Petra had written on Holocaust-related topics. Both of them chose Holocaust-related topics for assignments for Peter's methods course during the fall. They both ended up at the same school, with Peter as their practicum advisor. And they both received practicum teaching assignments that included "Canada and World War II," a part of the Social Studies II course in British Columbia. Knowing that they were going to teach the same classes, they began collaborative planning early in the practicum.

In the meantime, Peter had been thinking about continuing research with studentteachers. He organized a weekly seminar with all five of the student-teachers he supervised. About halfway through the long (I3 week) practicum, struck by both their backgrounds and the productivity of their collaboration, he approached Dan and Petra about writing a collaborative account of the year.

The methodology they employed can be called collaborative action research. It involves an intertwined investigation into the practices of the authors, who occupied different positions in respect to the processes of teacher education (Bullough \& Pinnegar, 200I). The data consist of assignments, both from the methods course itself, and from courses Dan and Petra took prior to the teacher education program. They also include Peter's course outline, and his comments on the assignments, transcripts of discussions among the three of us, entries into reflective journals, video-recordings of Petra's and Dan's teaching, and retrospective reflections on the experiences of the year. Some of these blur the traditional distinction between data and data analysis. Somewhat arbitrarily, we treat transcripts and journal entries made during the course of the program as textual data. On the other hand, we consider the three authors' retrospective reflections to be a first stage of drafting the article, and thus use no quotation 
marks even if we are working from our own reflective texts (e.g., Dan's paper, entitled “Teaching a Story About World War II”).

\section{Part I: Before the program}

\section{Peter}

When student-teachers arrived in September, Peter had been teaching in the teacher education program for Io years, since I990, and had just received an appointment as full professor. Leaving the high school social studies classroom had transformed his professional life. Prior to coming to UBC, he had spent the 15 years as a teacher in a variety of Vancouver schools, punctuated by part-time work for an M.A. in the History of Education in the I970s and then a Ph.D. in U.S. social history in the early I980s.

His initial interest in pursuing more history blossomed in the intellectual hothouse of the historiographic revolutions of those decades. His work at the intersection of social welfare history, the history of children, and labour history exemplified the writing which was generating excitement at the time. These were not lessons he could bring directly back to the classroom, but he was stimulated by being part of the transformation of the historiographic enterprise.

Peter began work at UBC's Faculty of Education with a mixture of wonder and bewilderment: having read virtually no educational research (other than the history of education) since his entry into teaching, he had little sense initially of how he would synthesize the fruits of his earlier teaching career and his formal training in history, in a program of educational scholarship.

Reading the work of history education researchers associated with the British Schools History Project (SHP), he saw an important opening. The SHP took as a starting point for research, young people's ideas about the nature of historical knowledge (Lee \& Ashby, 2000; Shemilt, 1980). Their notion of second order historical concepts - like evidence, cause and empathy (which might be construed as a Brunerian "structure of the discipline" of history, thus recalling lessons from his own teacher education in 1970)-provided an initial framework which he recast and reordered so that they would capture the historiographic transformation that had enlivened his encounters with history. If historians were dealing with contemporary cultural changes by rewriting history, he thought, then students thinking historically from the vantage point of the same contemporary culture, would share, in some form (again, recalling Bruner) the concerns that historians were attempting to address. Thus, he put "significance," mentioned in the British literature but hardly central, alongside "evidence." The reordering of historical significance was one way of understanding the historiographic revolution: women, workers, and ethnic minorities whose lives had been largely neglected in historical writing, were now placed at the center. In a similar way, the second order concept of "cause" was replaced by "agency." Understanding the agency of subaltern groups (and the limits upon it) was similarly a focus for the new historiography (Seixas, 1996). In this literature, the idea that historical writing should or could achieve the status of a science by eschewing moral and political judg- 
ments was entirely foreign. Academic historiography thus informed Peter's approach to history education, and yet it did so in a way that opened the doors to the concerns which the term "memory" addressed most centrally: that people in the present feel personal connections to the past, that the past bequeaths moral legacies, and that these legacies demand various kinds of "working through" (Simon, Eppert, \& Rosenberg, 2000). How these judgments are constructed, defended and presented makes all the difference.

Peter used these ideas to develop a rough and open theory of historical understanding, which provided the basis for an empirical research program on young people's ideas. He quickly discovered that he was not alone in North America in this pursuit: a small group of researchers in the United States soon coalesced, tackling similar questions with a variety of methodologies (Stearns, Seixas, \& Wineburg, 2000).

Alongside the research program, Peter introduced these ideas into his curriculum and instruction courses in the teacher education program. The program was, however, riddled with problems, perhaps the most significant of which was the fragmentation and lack of coordination among the various courses that students took (Segall, 2002). In 1998 , he joined with two colleagues to initiate a more coherent, integrated approach with 36 student-teachers each year: the Humanities and Social Justice Teacher Education Project. His major contributions to the program involved teaching the social studies methods course, supervision of a number of student-teachers, and the ongoing collaborative efforts necessary to coordinate the entire project. In the third year of the Project, Petra and Dan arrived at UBC.

\section{Petra}

It is somewhat ironic that Petra ended up in the Humanities and Social Justice Teacher Education Project. She came out of high school having taken a science program, and had started her post-secondary schooling doing the same. At the time she believed that science held both interest and career promise, and that history and geography were innately boring. She did not have terrible social studies teachers in high school; she just cannot remember anything that they taught her. She went to class and listened passively. It was not until college that she began to have a better understanding of history and what it could mean for her.

In her third term at Kwantlen University College in Surrey, she enrolled in a course in Canadian history to fulfill the six credits of Canadian content required to enter the Faculty of Education. This yearlong course had a profound impact. Her history professor required students to examine primary documents every week, a practice foreign to her high school experience. During this course she began to think about history entirely differently: she began to read ahead and look at historical documents as interesting artifacts waiting to be explored, rather than boring agglomerations of information that she was expected to absorb. She had always known that she wanted to teach, but it was during this course that she decided to teach social studies rather than science. Thus, she transferred from science to arts, where she immersed herself in history and geography. 
From Kwantlen, she moved into the History Department at UBC, where she took a course on the Canadian West. The instructor gave students considerable latitude in selection of assignments. Though unaware of it at the time, Petra realized in retrospect (during the teacher education program) that she had consistently made her assignment choices on the basis of opportunities to work with primary documents and testimony.

One assignment for this course provides an opportunity to examine Petra's sense of history and memory at the time. In part because it was a creative assignment with considerable leeway for students, we can use it to glimpse her ideas about the use of questions to frame historical narratives, as well as her treatments of historical evidence, historical empathy, and the moral judgments that are embedded in historical interpretation. While giving her a sense of personal connection to the past, the paper also opened up issues raised by World War II in ways that she would revisit on campus and on the practicum in the teacher education year.

She interviewed her three living grandparents - one British and two German - about their experiences during the war, using the transcripts as the basis of her paper. In broad strokes, the paper took the form of a narrative, with the hardship of the war in Europe sending both German and English grandparents to Canada for a better life. If Petra started with the question, "how did the War affect my family?" she ended with a much larger set of conclusions about the nature of post-war, multicultural Canada. European poverty and animosity were mended, in this account, through the passage of time and passage to the New World. "World War II," she observed, "brought enemies together and gave people a sense of community and a sense of family" (pp. I6-I7). ${ }^{1}$

As a young adult getting to know her grandparents in a new way through the oral history project, Petra treated their testimony largely at face value. Some of her observations, based on the German grandparents' interview, called out for some corroboration or explanation, or at least a sense of doubt: "The young people in Germany," Petra reported, "seemed to like Hitler, but the older people realized he would bring about nothing but turmoil" (p. 5). During the war, "most, if not all of the German prisoners had no idea what was going on back in Germany. All they knew was that they were supposed to fight for their country" (p. Io).

From the vantage point of the present, it is hard to know whether her critical historical sense was significantly less developed than it is today, or whether she deliberately suspended that sense, out of respect for her grandparents' memories and care for her relationship with them. Perhaps her approach to evidence in this instance was the result of a combination of the two factors. As she surmised, looking back:

I'm looking at it at face-value, I didn't question what-I mean I did in the back of my mind question what my grandparents said, and at times I wondered if some of the things that my grandfather said were actually true, and I thought he actually thinks they're true, though they may not be... at that time, I thought that I wanted to validate what they believed was true, especially my German grandparents, because they are so difficult to talk to, and when they started talking about this [their memories of the war], they were quite open and very excited about 
talking about this, and I did not want to disturb that. Because they're very sensitive people...(Research discussion, May 25, 200I)

The major accomplishment of the paper was its conveying a sense of what her grandparents experienced, or what they remembered as having experienced. Petra bridged the distance between their past and our present-historical empathy-by giving her grandparents themselves ample voice. If at times she suppressed her own critical scrutiny in doing so, her achievement was a strong sense of her grandparents' own viewpoints.

For my German grandparents, the war brought them closer together, and at the same time, it also tore them apart. My grandparents were apart for six years, but they learned to appreciate everything they had when it was all over. My grandfather did not get to see his son until he was four years old, but he did not think about what he had lost; he only thought about how lucky he was to return. (pp. IO-II)

Thus, the grandparents bridged the distance between memory of the European war and consciousness of the Canadian present; and Petra reported the story largely as they told it.

The same passage exemplifies Petra's approach to judgments about the war experience. Again, the major judgments (involving appreciation, loss, luck) are those of her grandparents. Other than setting these in a larger narrative of progress in peace and multiculturalism, in this paper Petra refrained from introducing her own judgments of actions, characters, or events.

After finishing this course and others, Petra completed her UBC degree. Then, with excitement about the prospect of teaching history, considerable undergraduate experience in working with primary sources, and a sense of the possibilities of constructing historical narratives that had deep personal connections, she entered the teacher education program.

\section{Dan}

Dan's family, like Petra's, provided an important piece of the context for his writing about history prior to the practicum. He grew up as a dependent in an American Foreign Service family that traveled around the world. His family's mobility, along with his work at the Vancouver Holocaust Education Centre and his related graduate study at Simon Fraser University were key influences in his understanding of history. The Holocaust Education work provided him, of course, with a different entry to thinking about the meanings of World War II.

He credits being a "foreign service brat" with preventing him from becoming embedded in the memory of any one people or geographical area, while at the same time encouraging a sense of "the varieties of history". His childhood let him know that the world could not be explained by one story and was the groundwork for an appreciation and toleration for complexity in history. 
In addition to his travel, family talk also had an impact. Whether it was around a dinner table, in a car or in the living room, family discussions often centered on history, current affairs and politics. From a very early age, he thought it normal that discussions about the world - the past, present or future of it-would be part of everyday life, and, by extension, his own. As with Petra's family interviews, these conversations planted a seed that later made it easier to see history as a study that could bear deep personal connection and meaning. Family conversations also reinforced his nascent sense of history's complexity, and the connections between past and present. Often his father would play devil's advocate or tell him of the possible historical reasons for why a certain people took seemingly inexplicable positions that they did.

More recent influences on his understanding of history were his time working at the Vancouver Holocaust Education Centre (VHEC) and his study of the Holocaust at Simon Fraser University. His three years as researcher and docent for the VHEC were important for two reasons: first, it was here that he became excited about the idea of teaching. Second, because of the VHEC's extensive use of artifacts, oral testimony, and primary documents, he gained a greater appreciation for how the story of something from long ago could be put together today-in essence, for the practice of history. Before these three years at the VHEC, he had given little thought to how history was constructed in the seamless narratives of the books he had read.

After his first year with the VHEC was completed, he began a two-year long Master's program on the Holocaust at Simon Fraser University. His program was interdisciplinary and involved examining questions such as "why do people commit evil?"; "how is the past used and constructed?"; and "how was religious thinking affected by the Shoah?". At the end of his two years of study, he submitted as his thesis, a model curriculum for a six-month-long grade I2 class on the Holocaust (Fromowitz, 2000).

Like Petra's undergraduate history essay, Dan's Master's thesis provides a window on his thinking about history prior to entering the teacher education program. Unlike Petra's paper, Dan's was constructed as a teaching curriculum, notwithstanding the facts that no members of his supervising committee were from the Faculty of Education and that he had not taken any education courses when he wrote it. Substantively, the most obvious difference from Petra's work was Dan's assessment of public knowledge of the extermination campaign. Dan wrote of evidence showing "that the Final Solution, or at least the idea the Jews were being killed in large numbers to the east, was known to be circulating around Germany" (p.I27). Rescue, he wrote, "remains the exception to the story" (p.I24). The question of the mental world of the German people, and the relationship between the people and the leaders during the Nazi regime would enter into the unit that Dan and Petra planned collaboratively.

Dan was conscious of the importance of "ask[ing] difficult questions" (p. 2): "Good history is not simply a retelling of the past, but something with which to grapple... Tempting as it may be to teach the Holocaust in a very simple 'good versus evil' model, a good educator must avoid spoon-feeding easy answers to students" (p. I8). Dan's sense that teaching involved a set of problems to be solved, and therefore that formulating the right questions comprised an important part of the process of teaching history, pre-dated his entry into the teacher education program. But the 
relationship between these questions and the historical narrative were quite different from what Peter taught in the social studies methods class, where questions were the starting point for organizing narratives. Dan's curriculum, in contrast, took the form of a narrative, with boxed "Question Breaks" followed by "Ideas for Answers." Thus, the narrative framed the questions.

Dan's experience with using historical evidence led him to include primary sources in the curriculum, but, as with the questions, he inserted them throughout the narrative to support it. He used the documents to illustrate, rather than to build the narrative. Thus he missed the dynamic negotiation between text and context so crucial to the building of historical knowledge (Seixas, 1998). This stands in contrast to the way he and Petra would use primary sources in their own teaching.

Dan recognized the problem of the distance between our ideas in the present and those of the historical actors in the past. He proposed a way to overcome it. He noted, "The principle organizing the curriculum is historical chronological. This approach allows students and teacher to encounter the history of the Holocaust as it happened and to avoid-as much as possible-using hindsight to interpret meaning" (p.iii).

He hoped that by working chronologically, students would understand the contingency of each set of decisions as they came along, engaging students "in the active reliving of the events from 1933 to 1945 " (p.iv). This was an acknowledgement of the problem of historical empathy, but quite a different formulation than Dan and Petra would build into their teaching unit, when they understood that one is always looking back from the present, and that the challenge is to be aware of that vantage point.

Finally, simply by choosing the Holocaust as his topic of study, Dan took on the problem of moral judgments about the past in one of its most extreme forms. He approached it with caution. "History is too easily judged when examined through a modern-day lens. ... [I]s a better approach one that understands the complexities of the time? ..." (p. I6). He was uninterested in leading students to facile condemnations. He felt that asking a student, "wasn't the Holocaust horrible?" - which indeed it was - to be a shallow question, one that not only prevented a better understanding of the past, but also potentially made the study of the Holocaust less relevant for the present.

Thus at the time of his entry into the teacher education program, Dan had thought a lot about the Holocaust as a pedagogical problem and had developed some rudimentary ideas about teaching. His work over the next year would develop these considerably.

\section{Part II: History in the methods course}

Retrospectively, Petra and Dan independently identified a number of the same lessons and exercises in the methods course as contributing most significantly to transforming their sense of what teaching history would involve. Early in the course, student-teachers were required to begin formulating generative questions, of the kind that could become curriculum organizers for entire teaching units (Osborne, 1995; Wiggins \& McTighe, I998; Wiske, 1998). Petra identified this exercise as giving her a fundamental 
structure for organizing teaching. It gave her a sense of where she was going and often shaped how she would get there. She could see how relating the unit to a specific question could help students with understanding by giving them something to look for throughout all of the lessons of a particular unit. Dan referred to the utility of the large, generative question in designing his own first unit on the Canadian West, whose title, "Westward Expansion: Creating a Nation or Destroying Nations?" presented just such an issue. While referring to a historical phenomenon, it also had a clear moral dimension. The task would be to handle the moral dimensions in a complex way, with respect for the historical evidence and historical actors.

Another set of lessons in Peter's methods class aimed at developing exactly these capacities. Exercises which focused on the construction of question sequences to help students analyze historical texts-film, photographs and written documents-were transformative, according to both Dan and Petra. In Dan's work at the Vancouver Holocaust Education Centre, he had seen documentary sources as evidence to back up a more or less completed narrative. His M.A. thesis reflected this approach. In the methods class, the order was reversed: the documents came first. By being forced to start with the formulation of questions around documents, he began to think of sources as the basis for the development of the narrative that students would learn. This complex shift did not happen instantaneously. In the course assignment, he chose three documents related to Canada's response to the Holocaust (ones he would eventually use in the unit with Petra): two 1938 entries from the diary of Prime Minister Mackenzie King, and a 1942 press statement from Department of External Affairs. Dan noted at the time how difficult it was, as someone who had studied the Holocaust for a number of years, to design an exercise for students who did not share his own background (Assignment \#4 Questionnaire). But while he formulated good questions of the individual documents, he initially had difficulty synthesizing the documents into a larger narrative or analytical whole. Peter responded at the time:

What is missing here, is something tying together these three documents, after the analysis of each individual one is complete. What big understandings do you want to leave students with, and what question and/or activity will you use to bring them to that point? (Document Based Lesson Assignment comments, Oct., 2000)

As Dan mastered this lesson, he not only had a new conception of how to use material in the classroom, but his own concept of doing history was changing as well.

Petra recalled a comparable challenge and a comparable shift in her thinking about teaching history as a result of these exercises. Though, as we have seen, she had considerable experience using primary sources, it had never occurred to her that they might constitute an important element of pedagogy. She now began to think about how an entire lesson, not just a lesson supplement, could be based on primary documents. She chose a series of documents related to Nazi Germany, which she and Dan would eventually use during the practicum: Lloyd George's misguided assessment of Hitler, a photograph of a Nuremberg Rally in 1936, and a speech by Rudolf Hess on 
the nature of loyalty, obedience, and Hitler's leadership. At the time, she noted the difficulty of assembling an appropriate sequence of questions, and of "relating all three of the sources together and coming up with a main point(s) [sic] that I wanted to make" (Assignment \#4 Questionnaire) (Seixas, 1998). She wrestled with questions of the mechanisms of Hitler's appeal to the German people-how were they thinking, and what caused them to think that way? - and with how to get her own students to wrestle similarly. Again, Peter offered comments at the time:

Your objectives are good, but given your documents, you could focus your objectives more narrowly, towards images of the Nazi leader, and the Nazi cult of the Fuhrer. Excellent choice of documents: short, simple, but full of analytical possibility (Document Based Lesson Assignment comments, Oct., 2000).

Dan's questioning of historical texts in the Westward Expansion unit began with two oral histories, the recollections of a white settler whose family tried to eke out a living on the prairies and a speech by a Native person telling two white travelers that they could not pass through their territory. He used carefully sequenced questions to lead students through the two accounts, asking finally, "How could the same event be portrayed so differently?" On a very basic level, he was asking students to think about the relationships among history, evidence, perspective and interpretation.

Dan concluded that he-someone who had a fairly strong history resume before going through any teacher training-had not fully grasped some relatively basic concepts relating to thinking about history, and would therefore not have been able to pass them on to students in any meaningful way, without the teacher education program. He felt confident, at the end of the course, that his exposure to these basic concepts would enable him to design richer and more useful assignments for his own history classes.

\section{Part III: Teaching World War II}

During the practicum, Dan and Petra planned two units together for Grade II Social Studies, "Canada in the 2oth Century": the first on the Depression, and the second on World War II. They were teaching in an upper middle class school, most of whose students were first or second-generation Asian immigrants. The family and community memories that had provided the starting points for their own thinking about World War II were not going to meet with immediate recognition among these young people. On the other hand, the multicultural classroom in which they found themselves was in part a legacy of changed ideas about race and nation in the wake of World War II.

Both of their sponsor teachers utilized lectures predominantly, and their students were quite accustomed to relatively passive and silent learning. Dan and Petra thus had an uphill battle to implement the discussion- and inquiry-based classrooms they had envisioned in the methods course. By the time they reached the World War II unit, however, they had been largely successful in establishing smooth and productive working relationships with the students, the teachers, and each other. The unit they 
designed was multifaceted, but focused on Canada in World War II, in accordance with the prescribed curriculum, with enough attention to international developments to allow students to make sense of the Canadian story.

Dan and Petra's different perspectives on the unit were more evident in the planning than in the teaching. By the time they entered their respective classrooms, they had worked out a common set of questions and materials. They started the unit with a modification of Petra's methods class assignment. The purpose of this lesson was to have students examine Hitler's appeal to Germans - not, of course, to justify popular support, but to help them to understand "ordinary Germans" views at the time. As Dan put it, they wanted students to move beyond an easy formula, "democracy good, totalitarianism bad." (Three-way discussion, March 28, 200I). In her journal, Petra recorded the challenge which Dan delivered to her over the lesson.

Dan called me up the other night and we started talking about why I wanted to teach this lesson and whether or not I felt some sort of responsibility to show students that not all German people were evil. I guess I wanted them to get the sense that all sorts of people were desperate at this time and that many turned to totalitarianism as a last hope. I wanted students to realize that Hitler was offering the German people something that they thought they needed and that he played on their emotions. I put some of this lesson together before I even knew that I would be teaching WWII.

I hadn't really thought about it all that much, but I guess I felt a little guilty; I felt as though I had to explain my heritage. I still feel a little guilty about what happened during the war, and I did not want students to blame everything on the entire German population. I wanted them to understand that these were desperate times. I, in no sense, wanted to excuse the atrocities that occurred because of Hitler's reign, but I did want students to think about the issues from every perspective. (Petra's Reflections, March 28, 200I)

Though Dan did not start from the same place as Petra-he had no potential issue of a heritage of German guilt - the lesson also fit well with his own approach to the Holocaust. The intent behind this opening lesson was to make it difficult for students to dismiss the appeal that totalitarianism held for people, and more specifically, to prompt students to think about reasons for why people followed a man like Hitler. With pictures, voices and statistics from the Great Depression fresh in their minds, students could better appreciate the idea that bad economic times could lead to support for totalitarian fascism (or communism). In addition to presenting plausible explanations for why Germans were drawn to Hitler and fascism, the lesson pointed out that many voices-like those of Lloyd George and Mackenzie King-in the earlyto mid-1930s acquiesced in the rise of Nazism. Close analysis of photographic and textual sources provided a basis for students' reasoning about the appeal. The lesson was designed to challenge the student who might say: "How could they all have been so stupid? I would never have believed or done that!" Retrospectively, Dan feared that 
focusing on what attracted people to fascist or totalitarian regimes may have left students not fully appreciating the record of brutality associated with these ideologies.

Dan and Petra were working with students on all four of the competencies involved in moving beyond the mere transmission of memory. They had a large question involving moral judgment; they helped students move towards historical empathy to understand the situation at the time; and they used documentary evidence to do so. And yet they had doubts about whether the interpretations they had implicitly constructed through this particular set of challenges for students had been off-base in some way. The seemingly open-ended inquiry carried with it a narrative moral that Dan and Petra needed to scrutinize anew after their classes. Throughout the unit, this cycle of designing inquiry and selecting sources, teaching the class, and reflective reconsideration was repeated a number of times. In examining Canadian participation in the battle at Dieppe, they noted that the textbook, Canada: A Nation Unfolding, did the work of analysis and judgment for the students, presenting Dieppe as a closed case and removing the reader from active involvement with the evidence. ${ }^{2}$ Their own exercise forced students to construct their own narrative-based on interpretations of oral history accounts of the battle, and a secondary account written twenty-five years after the battle. ${ }^{3}$ Petra explained:

I gave them documents saying that it was a success and saying that it was a failure, and I didn't tell them what I thought...they asked me what I thought, and I told them that it wasn't important what I thought... I wanted them to figure it out for themselves... I gave them as much information as I could have from both sides. (Research discussion, May 2, 200I)

During a three-way discussion (March 28, 200I), Dan explained the relationship between narrative and the kind of question that framed these lessons:

... if there is an overarching goal, it's to tell the "story" of WWII, but, within each lesson, there is some kind of "bigger" question.... For example, [in the] first lesson, we started off with just a general question, "What is totalitarianism?", comparing it to democracy, and asking what would draw people to totalitarianism.... and then we followed that up with a brief, general overview of what was going on in Germany, Italy, around the world.... And then at the end, we looked at Petra's really good document-based lesson.... [T] hat's an example of a lesson, having a nice, general theme to think about, but also moving the "story" of WWII along.

They sustained this complex relationship between developing a narrative while at the same time having students confront a series of questions that linked World War II to issues in the present. A central thread throughout the unit was a fundamental question: what, if anything, could justify the horror and sacrifice that engaging in war entailed? While the question could be posed generically, it had particular meaning in the context of World War II and the fight against fascism. In fact, the answer to the 
question provided the narrative they were constructing with its moral valence: either Canadian involvement in the war was meaningless sacrifice and suffering, or it was a necessary contribution to a hopeful future.

Sub-themes complicated the plot-line and the moral deliberations. A lesson on the Japanese-Canadian internment-recalling the first lesson on Hitler's appeal to Germans-aimed to make it easier for students to comprehend wartime paranoia. The class focused not only on the experience of the internees, but also on understanding the actions of the perpetrators. The lesson on Japanese Internment closed with three difficult questions. They first asked students to evaluate the claim that the internment of Japanese-Canadians was purely a response to the Japanese internment of Canadian soldiers. They pointed out that German-Canadians, while at times experiencing abuse and mistreatment by their fellow citizens, did not suffer the same degree of discrimination as Japanese-Canadians. Second, students were asked if they felt that the redress payment of \$2I,000 should "put this history to rest. Why or why not?" And finally, they were asked if studying the internment of Japanese-Canadians should be given a lower priority than the study of important battles and sacrifices made by Canadians during World War II. The strength of these questions lay in the recognition that "history" is not only about "what happened"; it is also about how the happenings of the past are interpreted, remembered, dealt with (or not), and presented-in the classroom and elsewhere. If students could see that these judgments and choices, which change with changing circumstances over time, shape how we think about the past, then they would have greater appreciation-and wariness - for how history and memory are constructed.

Dan and Petra returned to the central unit question by showing the first twenty minutes of Saving Private Ryan. D-Day-or Steven Spielberg's version of it-brought the student face to face with the consequences of fighting. Visualizing oneself coming off an amphibious landing vehicle, facing a stream of machine gun and mortar fire and scores of dead comrades, not to mention the Herculean task of taking a beach, would serve, at the very least, as an antidote for the notion of war being glorious that often infects young minds. To ensure the full impact, they mentioned to the students the film depicted a successful military operation. Students did respond to the power of the medium. All three of Petra's classes were stunned into silence at the end of the film (Research discussion, May 2, 200I). Under questioning in Dan's class,

one student said that wars can be necessary, but never right... The next few students who spoke up were adamantly against war, and said that the film had really changed their minds on the question of war being justified. One student said that "it's just not worth it", while the next, a student who often does contribute but who never has appeared really interested in the material, made an eloquent speech for three minutes on how devastating war is and how terrible the experience is. This student said he had now changed his mind-he really looked moved and troubled. (Dan's reflective journal, April 27, 200I) 
But the potent emotional and experiential tool of contemporary Hollywood film clearly had drawbacks in terms of the objectives of the unit. It offered an unearned shortcut to historical empathy, in that students achieved a sense of "what it was like" without having to weigh and consider historical evidence. The power of the cinematic clip also tipped the balance in questions of judgment: was going to war justified? With this horror? The consequences of fighting were plain to see, but it is questionable if the consequences of not fighting were adequately presented in the same scene.

Perhaps ironically, Dan and Petra decided not to use comparable graphic representations of the Holocaust. The nature of European anti-Semitism, the steps that led to the Nazi extermination campaign, and the Allied and specifically Canadian responses to the plight of the European Jews were all taken up, with frequent use of documentary sources. Yet they had some retrospective concerns about whether they had presented the Holocaust in too detached a manner. Again, retrospectively, they wondered whether they could have sharpened these lessons to bring them more pointedly to bear on the unit question: is war ever justified, and specifically, was war justified in opposition to the threats posed by the Nazi regime?

They posed similar kinds of questions in relation to the dropping of the atomic bomb, and they were similarly self-critical, retrospectively. Despite having well-crafted questions, they had not included documents giving evidence of the civilian experience of living through bombing raids. The question of targeting civilians during warfare was never examined, despite its close relation to the unit question. Rather, at the end of the unit, the theme was rather dryly recapitulated: with the death of approximately 55 million people, was the war "worth the effort." In a few days, then, the classes had covered the Holocaust, fire-bombing, the atomic bomb, and the total count of war dead-perhaps a mind-numbing survey of some of the major horrors of the 20 th century-and had been asked to consider the moral questions posed by catastrophe.

\section{Conclusion}

Obviously, this exercise is not presented as a model unit. Retrospectively, we all saw its problems. Rather, it allows us to examine the first attempts by two student-teachers, new to history teaching but carrying a rich and important set of their own memories. They worked collaboratively on large questions demanding moral judgments, on using documentary evidence critically, and on developing empathy across distance and difference. Their approach meant that the meanings of the War were relatively open, rather than fixed. But such relative openness raised new challenges even as it resolved older pedagogical issues.

The idea, central to the memorial impulse, that Canadians need to know about World War II primarily to honour the sacrifices of their dead forebears, was downplayed if not entirely absent from the unit. Rather, students engaged in a more openended inquiry into what happened, what it meant to those involved, and what it might mean for them in the early 2Ist century. Of course, the unit, by its very construction and design, through the incidents discussed and those omitted, through the sources read and those ignored, simultaneously highlighted and downplayed possible mean- 
ings of the Second World War. As much as we might want to label this pedagogy as induction into the practices of critical history, it was not without unarticulated consequences for the basic process of handing down memorial narratives through the school classroom. The questions and values that Dan and Petra (and Peter in the background) brought to this unit were shaped by memory, no less than history. Their family and curricular heritages had been shaped by ties with Europe. Now, in turn, with students whose families had deeper ties to Asia, they nurtured new narratives of Canada in the twentieth century, that would provide a new set of memorial frameworks-along with critical tools - with which the next multicultural generation would confront its futures in a new century.

\section{Notes}

I. Memory, family and identity worked in several ways for Petra: when her father was a child during the war, her German grandfather was in prison camp, and they were extremely poor. Her father's only toy was a doll which he called "Petra." As well, her German aunt married a Japanese-Canadian man, who had been interned in a camp in Canada (Research discussion, May 2, 200I).

2. In fairness, popular histories of Canada written by respected professional historians often take the same approach as the textbook. See McNaught (1988, p. 268) and Morton (1997, p. 225).

3. The beginning of Thinking historically: Narrative, imagination, and understanding (Holt, 1990)speaks to the need for students to construct their own narratives in history classes.

\section{References}

Banks, J. A., \& Parker, W. C. (1990). Social studies teacher education. In W. R. Houston (Ed.), Handbook of research on teacher education (pp. 674-686). New York: Macmillan.

Bullough, J., Robert V., \& Pinnegar, S. (200I). Guidelines for quality in autobiographical forms of self-study research. Educational Researcher, 30(3), I3-2I.

Fromowitz, D. (2000). Constructing a holocaust curriculum for grade twelve. Unpublished M.A., Simon Fraser University, Burnaby, BC.

Holt, T. (1990). Thinking historically: Narrative, imagination, and understanding. New York: College Entrance Examination Board.

Kammen, M. (1995). Review of Iwona Irwin-Zarecka, Frames of remembrance: The dynamics of collective memory. History and Theory, 34(3), 245-26I.

Kansteiner, W. (2002). Finding meaning in memory: A methodological critique of memory studies. History and Theory, 4I(2), 179-I97.

Klein, K. L. (2000). On the emergence of memory in historical discourse. Representations, 69, I27-I5O.

Lee, P., \& Ashby, R. (2000). Progression in historical understanding ages 7-I4. In P. Stearns, P. Seixas, \& S. S. Wineburg (Eds.), Knowing, teaching, and learning history: National and international perspectives. New York: New York University Press.

McNaught, K. (1988). The Penguin history of Canada (revised edition). London: Penguin.

Morton, D. (1997). A short history of Canada (3rd ed.). Toronto: McClelland \& Stewart.

Nora, P. (1996). Realms of memory: The construction of the French past. (Arthur Goldhammer, Trans.). New York: Columbia University Press.

Osborne, K. (1995). In defence of history: Teaching the past and the meaning of democratic citizenship. Toronto: Our Schools Our Selves Press.

Samuel, R. (1994). Theatres of memory. London, UK: Verso. 
Segall, A. (2002). Disturbing practice: Reading teacher education as text. New York: Peter Lang. Seixas, P. (1996). Conceptualizing the growth of historical understanding. In D. Olson \& N. Torrance (Eds.), Handbook of education and human development: New models of learning, teaching, and schooling (pp. 765-783). Oxford, UK: Blackwell.

Seixas, P. (1998). Student teachers thinking historically. Theory and Research in Social Education, 26(3), 310-34I.

Shemilt, D. (1980). History I3-I6: evaluation study. Edinburgh: Holmes McDougall.

Simon, R. I., Eppert, C., \& Rosenberg, S. (Eds.). (2000). Between hope and despair: Pedagogy and the remembrance of historical trauma. Maryland: Rowman and Littlefield.

Spiegel, G. M. (2002). Memory and history: Liturgical time and historical time. History and Theory, $4 I(2)$, I49-I62.

Stearns, P., Seixas, P., \& Wineburg, S. S. (Eds.). (2000). Knowing, teaching, and learning history: National and international perspectives. New York \& London: New York University Press.

Wertsch, J. (2002). Voices of collective remembering. New York: Cambridge University Press.

Wiggins, G., \& McTighe, J. (1998). Understanding by design. Alexandria, VA: Association for Supervision and Curriculum Development.

Wiske, M. S. (1998). Teaching for understanding. San Francisco: Jossey-Bass.

Yerushalmi, Y. H. (1989). Zakhor: Jewish history and Jewish memory. New York: Schocken Books. 
60 Encounters/Encuentros/Rencontres 